\title{
Effect of Dietary Supplementation of Prebiotics, Synbiotics, and Essential Oils on Growth Performance of Broiler Chicken
}

D.L.A. Sudharaka ${ }^{1}$, W.A.D.V. Weerathilake ${ }^{1 *}$, S.M.R. Samarakoon ${ }^{2}$, and D.M.D. Rasika ${ }^{1}$

\section{${ }^{1}$ Department of Livestock and Avian Sciences, Faculty of \\ Livestock Fisheries and Nutrition, Wayamba University of Sri Lanka, Makandura, Gonawila, Sri Lanka.}

${ }^{2}$ CIC Feeds (Pvt.) Ltd, Ekala, Sri Lanka

\section{Correspondence:}

*dammikaw@wyb.ac.lk

(iD) https://orcid.org/0000-0002-0954-8414

DOI: http://doi.org/10.4038/sljae.v3i1.61

\begin{abstract}
This study was performed to compare the effect of dietary supplementation of probiotics, prebiotics, essential oils and synbiotics on feed conversion ratio, live body weight and total feed intake of broiler chicken. A total of 800, day-old Arbor acres broiler chicks of either sex were randomly assigned into four dietary treatments. Each treatment had four replicates of 50 birds and were reared for over five weeks. Basal diet was supplemented with probiotics (control, T1), essential oils (T2), synbiotics (T3), and prebiotics (T4) as dietary treatments. The birds were provided with ad libitum feed and drinking water during the entire experimental period. At the end of 35 days experimental period there was no significant difference in live body weight, total feed intake and feed conversion ratio of broilers fed prebiotic, synbiotic and essential oil groups compared with probiotic supplemented control group. These findings reveal that, there is a potential to use prebiotics, EOs, and synbiotics as non-antibiotic growth promoters to improve broiler chicken's growth performances.
\end{abstract}

Keywords: Feed additives, Feed conversion ratio, Live body weight, Total feed intake 


\section{Introduction}

The broiler industry has shown a phenomenal growth over the recent past. The broiler industry has reached a step ahead with better performances of the birds (Yadav and Jha 2019). The condition and function of the gastrointestinal tract majorly associate with the health and performance of broiler birds (Clavijo and Flórez 2018). To modulate the intestinal microbiota, broiler feed is usually supplemented with antibiotics. Nevertheless, the emergence of microbial resistance to antibiotics in humans has caused an increased public and governmental concern in eliminating subtherapeutic usage of antibiotics in livestock and avian production (Landers et al. 2012). The European Union (EU) has banned the sub-therapeutic usage of antibiotics as growth promoters in animal production. This has created an interest in seeking alternatives for antibiotic growth promoters, which can be considered as natural and safe (Casewell et al. 2003).

Prebiotics are non-digestible carbohydrates such as mannan-oligosaccharides \& fructooligosaccharides, that beneficially effect on the host (Gibson and Roberfroid 1995). Previous studies have found that the dietary supplementation of prebiotics has a positive impact on growth performances in broiler birds (Hooge 2004; Mookiah et al. 2014; Yun et al. 2017). According to Huyghebaert et al. (2011), prebiotics are capable of selectively stimulating the proliferation or metabolic activity of a limited number of beneficial bacteria (e.g. Bifidobacteria and Lactobacillus species) in the colon.

Probiotics are live microbial feed supplements, which beneficially affect the host animal by improving its intestinal microbial balance (Jin et al. 1997). Based on the recent findings of Yang et al. (2012) and Bai et al. (2013), supplementation of probiotics has a positive impact on immunomodulation, gut health, growth stimulation and feed conversion efficiency of the host. However, those effects mostly relied on the specific strains of bacteria. Bacillus species, yeast, and lactic acid bacteria (LAB) are usually used as probiotics in animal nutrition (Fijan 2014). Based on the results of Ahmad (2006), probiotics are capable of maintaining beneficial microflora in the alimentary tract by competitive exclusion and antagonistic activity towards pathogenic bacteria.

Synbiotics include both beneficial microorganisms (probiotics) and substrates (prebiotics), which may have synergetic effects on the intestine of animals (Markowiak and Ślizewska 2018). Therefore, an appropriate combination of both components in a single product should 
ensure a superior effect, compared to the activity of either probiotic or prebiotic individually (Bengmark 2005; De Vrese and Schrezenmeir 2008). The principal aim of this type of combination is the improvement of the survival of probiotics in the intestine of the host by providing a better substrate (Markowiak and Ślizewska 2018).

Essential Oils (EOs), also known as aromatic oily liquids, are obtained from plant materials. They are complex mixtures of secondary plant metabolites consisting of low-boiling-phenylpropenes and terpenes (Brenes and Roura 2010). Cowan (1992) showed a wide range of antimicrobial properties of EOs. Besides antibacterial properties, EOs or their derivatives have exhibited hypolipidemic, antioxidant, digestive stimulant and immunomodulant properties. Based on the recent studies, dietary supplementation of broilers with EOs has a beneficial impact on the intestinal microflora (Helander et al. 1998) and digestive enzymes (Lee et al. 2003).

Therefore, the aim of the current research was to compare the effects of prebiotics, probiotics, EOs and synbiotics on the growth performance of broiler chicken.

\section{Materials and Method}

\section{Management and Feeding}

This study was carried out at a commercial farm located at Ja-Ela, Sri Lanka (7 3' 59.84" $\mathrm{N}$ and $79^{\circ} 53^{\prime} 36.66^{\prime \prime} \mathrm{E}$ ) from $24^{\text {th }}$ of July to $27^{\text {th }}$ of August 2020. A total of 800, day-old Arbor Acres broiler chicks of either sex were randomly assigned to four dietary treatments with four replicates of 50 birds in each. The experiment was carried out for five weeks. Paddy husk was spread on the floor as the litter material. Brooding was done up to 10 days of age. During brooding, the heat was provided by using a $250 \mathrm{~W}$ incandescent electric bulb to maintain a temperature of $32.5{ }^{\circ} \mathrm{C}$ in each pen for 50 birds. The behaviour of chicks was monitored frequently to ensure the brooding conditions. Up to $14^{\text {th }}$ day papers were laid on the litter to avoid chicks eating paddy husks. Feeders and waterers were changed according to the age and recommendations (Patrick and Ferrise 1962; Reed and Ringrose 1960). Feeders and waterers were cleaned and disinfected regularly. Birds were fed ad libitum with the formulated feed and provided fresh water with recommended quality (Mccreery 2015). All the chicks were vaccinated against Gamboro disease at $13^{\text {th }}$ and $19^{\text {th }}$ days of age. 
The treatments are presented in Table 1. Basal diet was provided by Chemical Industries Colombo (CIC) Feeds (Pvt) Ltd according to the company's ration.

Broiler chick booster (up to 10 days), broiler starter (11 to 20 days), broiler grower (21 to 28 days) and broiler finisher (29 to 35 days) were provided based on the instructions given by the feed manufacturer, to match the nutritional requirements of the birds.

Table1. Details of the experimental diets

\begin{tabular}{cl}
\hline $\begin{array}{c}\text { Treatment } \\
\text { No. }\end{array}$ & \multicolumn{1}{c}{ Treatments } \\
\hline T1 & Basal diet + Probiotic (control) \\
T2 & Basal diet + EOs \\
T3 & Basal diet + Synbiotics \\
T4 & Basal diet + Prebiotic \\
\hline
\end{tabular}

The composition of four different basal diets are given in Table 2. The composition and dosing rates of four different natural growth promoters (probiotics, prebiotics, synbiotics and EOs) are shown in Table 3. The concept of probiotics as a dietary treatment has earned a great attention and support. Significant number of research studies have increasingly demonstrated that probiotics positively affect in promoting the growth of broilers (Park et al. 2016). Accordingly, birds fed probiotic incorporated feed was used as the control.

\section{Body Weight, Feed Intake and Feed Conversion Ratio}

Initial body weight of randomly selected 25, day-old chicks in each replicate was measured and average weight of the birds in each replicate was calculated. Thereafter, the body weight of randomly selected 25 birds from each replicate was measured at weekly intervals and average weekly body weight was used for the FCR calculations.

A measured amount of feed was provided for each pen, and then, leftovers of each day were collected separately and measured. Daily feed intake per pen was calculated using above data. Daily mortality was recorded. Feed intake per bird per week was considered for the FCR calculations. Feed Conversion Ratio was calculated in weekly intervals using the following equation.

Weekly FCR $=\frac{\text { Weekly Fee d Intake }(\mathrm{g})}{\text { Weekly Bo dy Weight Gain (g) }}$

\section{Data Analysis}

The experiment was conducted as a completely randomized design (CRD), and live body weight, feed intake and FCR were analyzed using the one-way ANOVA procedure of the SPSS software programme (Version 16.0). Before submitting data to ANOVA, the conformity of data to the assumptions was tested. Statistical differences were considered significant at $p \leq 0.05$. Data were presented as means \pm standard deviation (SD). 
Table 2. Proximate composition of basal diets

\begin{tabular}{lllll}
\hline Basal Diets & $\begin{array}{l}\text { Special Broiler } \\
\text { chick Booster }\end{array}$ & Broiler Starter & Broiler grower & Broiler Finisher \\
& & & & \\
\hline Crude Protein \% (minimum) & 23.0 & 21.5 & 21.0 & 19.5 \\
Crude Fat \% (minimum) & 4.0 & 4.0 & 4.0 & 4.0 \\
Ash \% (maximum) & 7.0 & 7.0 & 7.5 & 7.5 \\
Crude Fiber \% (maximum) & 4.5 & 4.5 & 4.5 & 4.5 \\
Calcium \% (minimum) & $1.0-1.2$ & $1.0-1.2$ & $1.0-1.2$ & $0.9-1.2$ \\
Phosphorous \% (minimum) & $0.8-1.0$ & $0.7-1.0$ & $0.7-1.0$ & $0.65-1.0$ \\
Methionine \% (minimum) & 0.57 & 0.55 & 0.53 & 0.50 \\
Metabolizable Energy & 3000 & 3000 & 3100 & 3180 \\
(kcalkg-1) (minimum) & & & & \\
\hline
\end{tabular}

(Source: CIC Feeds (Pvt) Ltd)

Table 3. Composition and the dose rates of dietary treatments used in the diet

\begin{tabular}{|c|c|c|}
\hline Dietary treatments & Composition & Amount Incorporated $\left(\mathrm{gt}^{-1}\right)$ \\
\hline Probiotic & $\begin{array}{l}\text { Bacillus subtilis, Bacillus } \\
\text { licheniformis, Bacillus coagulans, } \\
\text { Clostridium butyricum HJCB998 }\end{array}$ & $\begin{array}{l}500 \mathrm{gt}^{-1} \text { of starter, grower and finisher } \\
\text { ration }\end{array}$ \\
\hline Essential Oils & $\begin{array}{l}\text { Rosmarinus officinalis oil } \\
\text { (Rosemary oil), Origanum vulgare } \\
\text { oil (Oregano oil), Cinnamomum } \\
\text { zeylanicum oil (Cinnamon oil) and } \\
\text { Capsicum annuum extract (Chili } \\
\text { pepper extract) }\end{array}$ & $\begin{array}{l}150 \mathrm{gt}^{-1} \text { of starter ration and grower } \\
\text { ration. } 100 \mathrm{gt}^{-1} \text { of finisher ration }\end{array}$ \\
\hline Prebiotic & $\begin{array}{l}\text { Phosphorylated mannan } \\
\text { oligosaccharides }\end{array}$ & $\begin{array}{l}800 \mathrm{gt}^{-1} \text { of starter ration and grower ration. } \\
500 \mathrm{gt}^{-1} \text { of finisher ration }\end{array}$ \\
\hline Synbiotics & Bacillus subtilis and prebiotic & $\begin{array}{l}500 \text { gt-1 }^{-1} \text { of starter, grower and finisher } \\
\text { ration }\end{array}$ \\
\hline
\end{tabular}

\section{Results and Discussion}

Results of the weekly mean body weight and feed intake are presented in Table 4 and 5, respectively.

\section{Body Weight}

The average bodyweight of the day-old chicks was $32 \mathrm{~g}$ (Table 4). All the birds were in good health condition during the experimental period of five weeks. The differences observed in body weight among the treatment groups were not significant $(p>0.05)$. In this study, birds were supplemented with a cocktail of probiotics 
Table 4. Average body weight (g/ chick/ week), of chicks fed diets supplemented with Probiotics, Essential Oils, Synbiotics, Prebiotics

\begin{tabular}{lcccccc}
\hline $\begin{array}{l}\text { Dietary } \\
\text { Treatment }\end{array}$ & Day1 & Day7 & Day14 & Day21 & Day28 & Day35 \\
\hline T1 & $32.0 \pm 0$ & $153.0 \pm 5.6$ & $434.7 \pm 13.2$ & $889.6 \pm 33.5$ & $1497.9 \pm 85.2$ & $2003.1 \pm 254.1$ \\
T2 & $32.0 \pm 0$ & $155.2 \pm 4.4$ & $427.2 \pm 38.3$ & $913.2 \pm 45.9$ & $1487.2 \pm 100.2$ & $1953.7 \pm 181.9$ \\
T3 & $32.0 \pm 0$ & $151.0 \pm 4.3$ & $431.8 \pm 15.6$ & $908.5 \pm 43.0$ & $1457.8 \pm 73.1$ & $1926.1 \pm 198.3$ \\
T4 & $32.0 \pm 0$ & $149.3 \pm 6.2$ & $453.8 \pm 14.0$ & $891.7 \pm 25.3$ & $1435.7 \pm 79.3$ & $1958.0 \pm 131.6$ \\
\hline
\end{tabular}

T1 = Control Group (probiotic), T2 - EOs-treated group, T3 = synbiotic-treated group and T4 = prebiotic-treated group. Values are means $\pm \mathrm{SD}, \alpha=0.05$

(Bacillus subtilis, Bacillus licheniformis, Bacillus coagulans, Clostridium butyricum HJCB998). Pelicano et al. (2004) reported that the magnitude of the body growth is directly affected by the variations in the strain and dose of the bacterial strain used as the dietary supplement. This could be the cause for the controversial results given by the probiotics as a natural growth promoter in different researches.

Although the differences observed in body weight among the treatments were statistically non-significant, the cumulative body weight of a bird in prebiotic supplemented group was numerically lower than control group. Similary, Sarangi et al. (2016) stated that addition of prebiotics had no significant effect on weight gain of broiler chickens. According to the results of the present study, blend of EOs showed no impact on body weight of the broilers. Those results agree with the findings of Botsoglou et al. (2002), where no significant differences of broiler chicken growth was observed using rosemary and oregano EOs alone or in combination. Moreover, Symeon et al. (2014) found that adding cinnamon oil at the concentrations of 0.5 or $1 \mathrm{mlkg}^{-1}$ to feed did not have the potential to improve broiler growth performance. However, the results of the present study were found contrary to the those of Puvača et al. (2019) who showed that supplementation of the diet with chilli pepper extract exhibits a positive effect on growth performances of the broilers. In contrast, Tiihonen et al. (2010) and Khattak et al. (2014) reported a significant increase in the live body weight of broilers supplemented with a blend of EOs than those fed with individual EOs.The present findings were in agreement with Sarangi et al. (2016) who reported that the dietary inclusion of synbiotics did not show any significant increase in body weight of broiler chickens. 
Table 5. Feed intake (g/ chick/ week), of chicks fed diets supplemented with Probiotics, Essential Oils, Synbiotics, Prebiotics

\begin{tabular}{llllll}
\hline Dietary Treatment & Day7 & Day14 & Day21 & Day28 & Day35 \\
\hline T1 & $196 \pm 14$ & $552 \pm 7$ & $1090 \pm 40$ & $1974 \pm 46$ & $2888 \pm 113$ \\
T2 & $193 \pm 5$ & $543 \pm 13$ & $1140 \pm 20$ & $2060 \pm 80$ & $3034 \pm 156$ \\
T3 & $203 \pm 20$ & $548 \pm 8$ & $1120 \pm 0$ & $1990 \pm 30$ & $2853 \pm 47$ \\
T4 & $218 \pm 218$ & $563 \pm 7$ & $1120 \pm 0$ & $1975 \pm 25$ & $2950 \pm 10$ \\
\hline
\end{tabular}

Means within a column with different superscripts were significantly different $(p>0.05)$. T1 $=$ Control Group (probiotic), T2 - EOs-treated group, $\mathrm{T} 3=$ synbiotic-treated group and T4 = prebiotic-treated group. Values are means \pm SD $\alpha=0.05$.

\section{Feed Intake}

The cumulative feed intake per chick was same for every group (Table 5). Similarly, Brenes and Roura (2010) and Bozkurt et al. (2014) had reported that the feed intake in broilers was unchanged or slightly reduced by supplementation of EOs. Halle et al. (2004) and Amad et al. (2011) reported that the feed intake of broilers was decreased by increasing the dietary level of a blend of thyme, and Origanum leaves, and it's associated with EOs compared with control. Accordingly, there can be an effect of composition and quantity of the EOs on the feed intake. In the present study, the impact of dietary supplementation of prebiotic, probiotic, essential oil and synbiotic on cumulative feed intake during the entire period of the experiment, was found to be non-significant ( $p>0.05)$.

Several other studies also showed that the supplementation of probiotics or prebiotics alone or in combinations as synbiotics had no significant effect on the feed intake of broilers (Mookiah et al. 2014; Sarangi et al. 2016; Jung et al. 2008; Olnood et al. 2015).

\section{Feed Conversion Ratio}

The FCR of the birds assigned to different treatments was ranged from $1.22 \pm 0.04$ to $1.55 \pm 0.05$ (Fig. 1). Over the first 21 days of treatment, there was a decreasing trend in the FCR values irrespectively of the treatment. However, after 21 days of treatment, there was a marked increase in the FCR values in all treatments up to the $35^{\text {th }}$ day. At the $28^{\text {th }}$ day, the FCR of the control group was lower than that of the EOs, synbiotic and prebiotic treated groups. The FCR values after the end of the experiment did not differ significantly between prebiotic, EOs and synbiotic group compared to control ( $p>0.05)$. The present findings were in agreement with several studies that reported no significant difference in FCR values between probiotics, prebiotics, and synbiotics (Mokhtari and Yazadani 2010; Sarangi et al. 2016). 


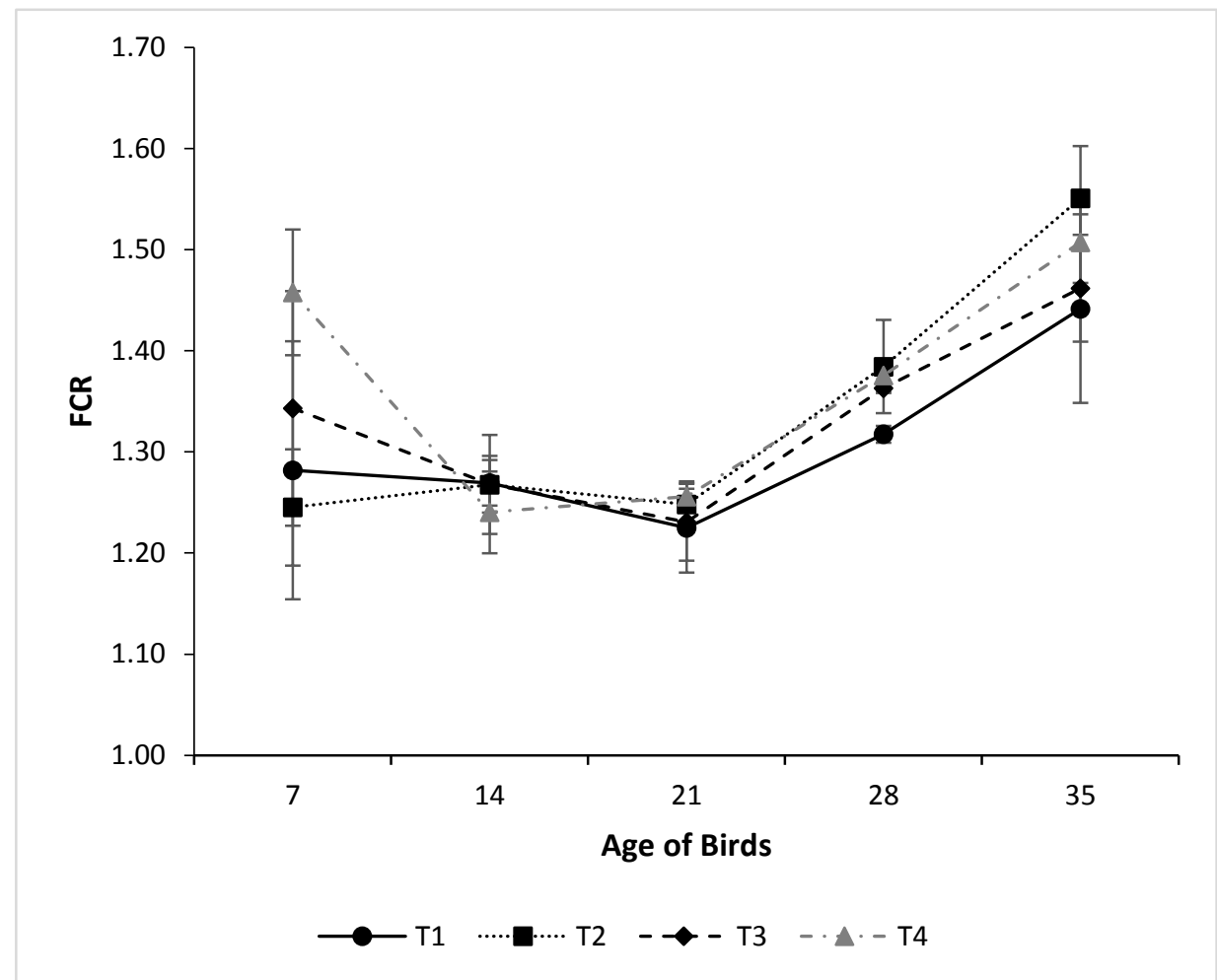

Figure 1. Changes in FCR of broilers fed diets supplemented with different dietary treatments over the experimental period. $\mathrm{T} 1=$ Control Group (probiotic), $\mathrm{T} 2$ - EOs-treated group, $\mathrm{T} 3$ = synbiotic-treated group and $\mathrm{T} 4$ $=$ prebiotic-treated group. Values are means \pm SD, $\alpha=0.05$

The results of the present study showed that there was no difference in inclusion of probiotics, essential oils, prebiotics or synbiotics on FCR. In contrast, Talebi et al. (2008), Wang and Gu (2010) and Harrington et al. (2015) observed that the inclusion of probiotic to broiler diets has decreased FCR significantly. Hassanpour et al. (2013) stated that synbiotics promote the growth of the probiotic by providing a specific substrate to the probiotic for its fermentation. The FCR of prebiotic-supplemented group (1.50 \pm 0.04$)$ was numerically higher than the FCR of the control group. Further, present findings were in agreement with Hernández et al. (2004) who found that the addition of EOs did not have any significant effect on the FCR of broiler chickens. However, the present observation was found not in concurrence with Hong et al. (2012) who reported that EOs feed supplementation significantly improved the FCR. Similarly, studies done by Guler et al. (2005) and Gao et al. (2010) also reported that dietary supplementation of EOs has a significant improvement of FCR in broilers when compared to the control group. 
There are evidences that the EOs have a positive effect on the production performance of broiler chickens. Two wellaccepted mechanisms of EOs are the stimulation of digestive enzyme secretion and the stabilization of ecosystem of gut microflora, leading to ameliorated feed utilization and less exposure to growthdepressing disorders related with digestion and metabolism (Bento and Ouwehand 2013; Brenes and Roura 2010; Zhai et al. 2018). The major cause for the contradictory results of the EOs treated group in the present study could be due to the variation in the efficacy of EOs. Growth performance and feed intake could be associated with the composition of the EOs mixture and inclusion level of the EOs (Yitbarek 2015). There are various types of herbs and spices used as phytogenic feed additives in poultry production. The impact of harvesting time, state of maturity of plants, extraction methods of plants, method and duration of conservation and storing, possible synergistic or antagonistic effect of the bioactive compounds may also affect to the results (Brenes and Roura 2010; Krishan and Narang 2014).

\section{Conclusions}

The present study did not show any significant effect on the body weight and FCR of the broilers by the dietary inclusion of prebiotics, blend of EOs, and synbiotics compared with probiotics supplemented control at the end of 35 days experimental period. Further studies should be conducted to confirm the present findings and evaluate the suitability of these natural growth promoters as promising alternatives for antibiotic growth promoters in broiler industry.

\section{Acknowledgement}

The authors gratefully acknowledge the financial support provided by the CIC Feeds (Pvt.) Ltd and the assistance and guidance provided by the Wayamba University of Sri Lanka.

Conflicts of interest: The authors have no conflicts of interest regarding this publication.

\section{References}

Ahmad I (2006) Effect of Probiotics on Broilers Performance. Int J Poult Sci. 5(6):593-597.

Amad A A, Männer K, Wendler K R, Neumann K, Zentek J (2011) Effects of a phytogenic feed additive on growth performance and ileal nutrient digestibility in broiler chickens. Poult Sci. 90(12):2811-2816. doi:10.3382/ps.2011-01515

Bai S P, Wu A M, Ding X M (2013) Effects of 
probiotic-supplemented diets on growth performance and intestinal immune characteristics of broiler chickens. Poult Sci.92(3):663-670. doi:10.3382/ps.201202813

Bengmark S (2005) Bioecologic control of the gastrointestinal tract: The role of flora and supplemented probiotics and synbiotics. Gastroenterol Clin North Am. 34(3):413-436. doi:10.1016/j.gtc.2005.05. 002

Bento M, Ouwehand A (2013) undefined. Essential Oils and Their Use in Animal Feeds for Monogastric Animals--Effects on Feed Quality, Gut Microbiota, Growth Performance and Food Safety: A Review. Accessed December 30, 2020. https://pdfs.semanti cscholar.org/e 217/65a0e945009385607b32df40c31acde 12453.pdf

Botsoglou N A, Florou-Paneri P, Christaki E, Fletouris D J, Spais A B (2002) Effect of dietary oregano essential oil on performance of chickens and on ironinduced lipid oxidation of breast, thigh and abdominal fat tissues. $\mathrm{Br}$ Poult Sci. 43(2):223-230. doi:10.1080 /0007166 0120121436

Bozkurt M, Aysul N, Küçükyilmaz K (2014) Efficacy of in-feed preparations of an anticoccidial, multienzyme, prebiotic, probiotic, and herbal essential oil mixture in healthy and Eimeria spp.-infected broilers. Poult Sci. 93(2):389-399. doi:10.3382/ps.2013-03368

Brenes A, Roura E (2010) Essential oils in poultry nutrition: Main effects and modes of action. Anim Feed Sci Technol. 158(1-2):114. doi:10.1016/j.anifeedsci.2010.03.007

Casewell M, Friis C, Marco E, Mcmullin P, Phillips I (2003) The European ban on growth-promoting antibiotics and emerging consequences for human and animal health. J Antimicrob Chemother.52:159-161. doi:10. 1093/jac/dkg313

Clavijo V, Flórez M J V (2018) The gastrointestinal microbiome and its association with the control of pathogens in broiler chicken production: A review. Poult Sci.97(3):1006-1021.

doi:10.3382/ps/pex359

Cowan M M (1992) Plant products as antimicrobial agents. Clin Microbiol Rev. 12(4):564-582. doi:10.1128/cmr.12.4.564

De Vrese M, Schrezenmeir J (2008) Probiotics, prebiotics, and synbiotics. Adv Biochem Eng Biotechnol. 111:1-66. doi:10.1007/ 10_2008_097

Fijan S (2014) Microorganisms with claimed probiotic properties: An overview of recent 
literature. Int J Environ Res Public Health.11(5):4745-4767. doi:10.3390/ijer ph110504745

Gao X, Zhao H, Feng Y, Zhao M (2010) A comparative study on physicochemical properties of Chinese-type soy sauces prepared using pure koji and mixed kojis. African J Biotechnol. 9(40):6740-6747. doi:10.4314/ajb.v9i40

Gibson G R, Roberfroid M B (1995) Dietary modulation of the human colonic microbiota: Introducing the concept of prebiotics. J Nutr. 125(6):1401-1412. doi:10.1093/jn/125.6.140 1

Guler T, Ciftci M, Dalkilic B (2005) The Effect of an Essential Oil Mix Derived from Oregano, Clove and Anise on Broiler Performance .Artic Int J Poult Sci. doi:10.3923/ijps.2005.879.884

Halle I, Thomann R, Bauermann U, Henning M, Köhler P (2004) Effects of a graded supplementation of herbs and essential oils in broiler feed on growth and carcass traits. Land Volke. 54(4): 219-229.

Harrington D, Sims M, Kehlet A B (2015) Effect of Bacillus subtilis supplementation in low energy diets on broiler performance. J Appl Poult Res. 25(1):29-39. doi:10.3382/japr/ pfv057
Hassanpour H, Moghaddam A K Z, Khosravi M, Mayahi M (2013) Effects of synbiotic on the intestinal morphology and humoral immune response in broiler chickens. Livest Sci. 153(1-3):116-122. doi:10.1016/ j.livsci.2013.02.004

Helander I M, Alakomi H L, Latva-Kala K (1998) Characterization of the Action of Selected Essential Oil Components on GramNegative Bacteria. J Agric Food Chem. 46(9):3590-3595. doi:10.1021/jf980154m

Hernández F, Madrid J, García V, Orengo J, Megías M D (2004) Influence of two plant extracts on broilers performance, digestibility, and digestive organ size. Poult Sci. 83(2):169-174. doi:10.1093/ps/83.2. 169

Hong J C, Steiner T, Aufy A, Lien T F (2012) Effects of supplemental essential oil on growth performance, lipid metabolites and immunity, intestinal characteristics, microbiota and carcass traits in broilers. Livest Sci. 144(3):253-262. doi:10.1016/j.li vsci.2011.12. 008

Hooge D M (1993-2003) Meta-Analysis of Broiler Chicken Pen Trials Evaluating Dietary Mannan Oligosaccharide. Vol 3.; 2004. Accessed September 30, 2020. http://citeseerx.ist.psu.edu/viewdoc/down load?doi=10.1.1.467.2581\&rep=rep1\&type $=\mathrm{pdf}$ 
Huyghebaert G, Ducatelle R, Immerseel F Van (2011) An update on alternatives to antimicrobial growth promoters for broilers. Vet J.187(2):182-188. doi:10.1016 /j.tvjl.2010. 03.003

Jin L Z, Ho Y W, Abdullah N, Jalaludin S (1997) Probiotics in poultry: Modes of action. Worlds Poult Sci J. 53(4):362-368. doi:10.1079 /wps19970028

Jung S J, Houde R, Baurhoo B, Zhao X, Lee B $\mathrm{H}$ (2008) Effects of galacto-oligosaccharides and a Bifidobacteria lactis-based probiotic strain on the growth performance and fecal microflora of broiler chickens. Poult Sci, 87(9), 1694-1699. https://doi.org/10. 3382/ps.2007-00489

Khattak F, Ronchi A, Castelli P, Sparks N (2014) Effects of natural blend of essential oil on growth performance, blood biochemistry, cecal morphology, and carcass quality of broiler chickens. Poult Sci.93(1):132-137. doi:10.3382/ps.201303387

Krishan G, Narang A (2014) Use of essential oils in poultry nutrition: A new approach. J Adv Vet Anim Res. 1(4):156. doi:10.5455/ javar.2014.a36

Landers T F, Cohen B, Wittum T E, Larson E L (2012) A review of antibiotic use in food animals: Perspective, policy, and potential.
Public Health Rep. 127(1):4-22. doi:10.1177/003335491212700103

Lee K W, Everts H, Kappert H J, Frehner M, Losa R, Beynen A C (2003) Effects of dietary essential oil components on growth performance, digestive enzymes and lipid metabolism in female broiler chickens.Br Poult Science. 44(3): 450-457. https://doi.org/ 10.1080/0007166031000 085508

Markowiak P, Ślizewska K (2018) The role of probiotics, prebiotics and synbiotics in animal nutrition. Gut Pathog. 10(1):21. doi:10.1186/s13099-018-0250-0

Mokhtari R, Yazdani A (2010) The effects of different growth promoters on performance and carcass characteristics of broiler chickens. cabdirect.org. Accessed December 30, 2020. https://www.cabdirect.org/cab direct/abstract/20103363485

Mccreery D H (2015) Water Consumption Behavior in Broilers.Accessed April 12, 2021.http://scholarworks.uark.edu/etdhtt p://scholarworks.uark.edu/etd/1301

Mookiah S, Sieo C C, Ramasamy K, Abdullah N, Ho Y W (2014) Effects of dietary prebiotics, probiotic and synbiotics on performance, caecal bacterial populations and caecal fermentation concentrations of broiler chickens. J Sci Food Agric. 94(2):341- 
348. doi:10.1002/jsfa.6365

Olnood C G, Beski S S M, Choct M, Iji P A (2015) Novel probiotics: Their effects on growth performance, gut development, microbial community and activity of broiler chickens. Anim Nutri. 1(3), 184-191. https://doi.org/10.1016/j.aninu.2015.07.0 03

Park Y H, Hamidon F, Rajangan C (2016) Application of probiotics for the production of safe and high-quality poultry meat. Korean J Food Sci Anim Resour. 36(5):567576. doi:10.5851/kosfa.2016.36.5.567

Patrick H, Ferrise A (1962) The Water Requirements of Broilers. Poult Sci.41(5):13631367.doi:10.3382/ps.04113 63

Pelicano E, Souza P de, Souza H de, Leonel F, Zeola N, Boiago M (2004) Productive traits of broiler chickens fed diets containing different growth promoters. Rev Bras Ciência Avícola.6(3):177-182. doi:10.1590 /s1516-635 x2004000300008

Puvača N, Ljubojević Pelić D, Popović S, Đuragić O, Peulić T, Lević J (2019) Evaluation of broiler chickens lipid profile influenced by dietary chili pepper addition. Accessed September 30, 2020.http://www. fimek.edu.rs/downloads/casopisi/jatem/is sue/v2_5/01(1)_Puvaca_et_al._2019._Vol._2 (5)_318-324.pdf
Reed W S, Ringrose R C (1960) Feeder Space Requirements of Broiler Chickens. Poult Sci.39(2):454-459.doi:10.3382/ps.0390454

Sarangi N R, Babu L K, Kumar A, Pradhan C R, Pati P K, Mishra J P (2016) Effect of dietary supplementation of prebiotic, probiotic, and synbiotic on growth performance and carcass characteristics of broiler chickens. Vet World.9(3):313-319. doi:10.14202/ vetworld. 2016.313-319

Symeon G K, Athanasiou A, Lykos N (2014) The effects of dietary cinnamon (Cinnamomum $\quad$ Zeylanicum) oil supplementation on broiler feeding behaviour, growth performance, carcass traits and meat quality characteristics. Ann Anim Sci. 14(4):883-895. doi:10.2478/aoas2014-0047

Talebi A, Amirzadeh B, Mokhtari B, Gahri H (2008) Effects of a multi-strain probiotic (PrimaLac) on performance and antibody responses to Newcastle disease virus and infectious bursal disease virus vaccination in broiler chickens. Avian Pathol.37(5):509512. doi:10.1080/03079450802356995

Tiihonen K, Kettunen H, Bento M H L (2010) The effect of feeding essential oils on broiler performance and gut microbiota. Br Poult Sci. 51(3):381-392. doi:10.1080/00071668 .2010 .496446

Wang Y \& Gu Q (2010) Effect of probiotic on 
growth performance and digestive enzyme activity of Arbor Acres broilers. Res Vet Sci. 89(2):163-167. https://doi.org/10.1016/ j.rvsc. 2010.03.009

Yadav S, Jha R (2019) Strategies to modulate the intestinal microbiota and their effects on nutrient utilization, performance, and health of poultry. J Anim Sci Biotechnol. 10(1):2. doi:10.1186/s40104-018-0310-9

Yang C M, Cao G T, Ferket P R (2012) Effects of probiotic, Clostridium butyricum, on growth performance, immune function, and cecal microflora in broiler chickens. Poult Sci. 91(9):2121-2129. doi:10.3382/ps.201102131
Yitbarek M B (2015) Phytogenics As Feed Additives In Poultry Production: A Review. J extensive Res. 3:49-60. Accessed December 30, 2020. http://www.journalijer.com

Yun W, Lee D H, Choi Y I, Kim I H, Cho J H (2017) Effects of supplementation of probiotics and prebiotics on growth performance, nutrient digestibility, organ weight, fecal microbiota, blood profile, and excreta noxious gas emissions in broilers. J Appl Poult Res.26(4):584-592. doi:10. 3382/japr/pfx033

Zhai H, Liu H, Wang S, Wu J, Kluenter A M (2018) Potential of essential oils for poultry and pigs. Anim Nutr. 4(2):179-186. doi:10.1016/j.aninu.2018.01.005. 